\title{
A hydrodynamic-ecological model for Lake Rerewhakaaitu
}

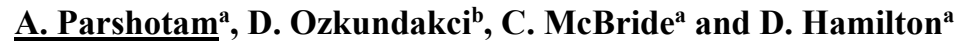 \\ ${ }^{a}$ LERNZ (Lake Ecosystem Restoration New Zealand), University of Waikato, New Zealand \\ ${ }^{b}$ Waikato Regional Council, Hamilton, New Zealand
}

Email: aroonp@waikato.ac.nz

\begin{abstract}
Lake Rerewhakaaitu is a shallow (average depth 7m, maximum depth: 15m) lake in the Rotorua region and is unique amongst the 12 Rotorua Lakes in that its catchment is the only one dominated by dairy farming as the main type of land use. At present, Lake Rerewhakaaitu is an attractive and popular lake with fairly good water quality, although over recent years the lake has shown signs of declining, water quality and biodiversity. It is essential that water quality in the lake is maintained or improved in order to retain the intrinsic, cultural and economic benefits the lake provides to the region. A computer modelling tool is required by lake managers to simulate current lake conditions and assess the potential impact of changes such as land use and/or inflows, and farm management practices. The purpose of this study was to implement, calibrate and validate the coupled hydrodynamic-ecological model, DYRESM-CAEDYM, to Lake Rerewhakaaitu.
\end{abstract}

The one-dimensional (1D) hydrodynamic model DYRESM (Dynamic Reservoir Simulation Model) was coupled with the aquatic ecological model CAEDYM (Computational Aquatic Ecosystem Dynamics Model). DYRESM is a process-based model with a Lagrangian layer scheme that is used to predict the vertical distribution of temperature, salinity and density in lakes. Inputs to DYRESM are lake morphology, daily meteorological data, daily inflow temperature and volume and daily outflow volume. The CAEDYM model incorporates the major biogeochemical processes influencing water quality: primary production, secondary production, nutrient and metal cycling, oxygen dynamics and movement of sediment. The inputs to the CAEDYM model are nutrient inputs and the outputs are the oxygen distribution in the water column, nutrient distribution in the water column (N, C, P, Si), phytoplankton/zooplankton, algae, and more.

Lake bathymetric data were obtained for April 2011. Meteorological data was obtained for the Rotorua Airport climate station about $20 \mathrm{~km}$ away from the lake. There are two stream inputs to the lake: Mangakino Stream and Awaroa Stream. Surface inflows were available for the Mangakino Stream and/or filled using rated flows in the permanently gauged Ngongotaha stream. Flows from the Awaroa stream were obtained from a regression equation relating Awaroa Stream flows to the Mangakino stream flows. Daily nutrient concentrations $\left(\mathrm{NO}_{3}-\mathrm{N}, \mathrm{NH}_{4}-\mathrm{N}, \mathrm{PO}_{4}-\mathrm{P}\right)$ for the Mangakino Stream were derived by interpolation between monthly samples. Suspended solid concentrations for the Mangakino Stream were obtained by using a regression equation relating flow rate and suspended solid concentrations. Labile organic nitrogen and phosphorus concentrations were calculated using monthly stream nutrient measurements and were evenly divided into dissolved and particulate fractions. For the Awaroa stream, an average daily concentration of nutrients and suspended solids were used. A further $7 \%$ of the catchment was assumed to drain directly into the lake. Lake surface outflows were assumed to be zero.

To calibrate the DYRESM-CAEDYM model, data from 2005-2010 was used and to validate the model, data from 2010-2015 were used. Parameters chosen were in the range given in the literature. Simulated concentrations of temperature, dissolved oxygen (DO), total nitrogen (TN), $\mathrm{NO}_{3}-\mathrm{N}_{1} \mathrm{NH}_{4}-\mathrm{N}$, total phosphorus, $\mathrm{PO}_{4}-\mathrm{P}$ and chlorophyll $a$, at various depths were compared to measured data from observations to evaluate model fit with model error represented by a series of model performance statistics. The calibrated coupled model may be used to predict water quality in Lake Rerewhakaaitu, and ultimately, as a tool to test various management change scenarios.

Keywords: Lake, modelling, hydrodynamic-ecological model, DYRESM, CAEDYM 


\section{INTRODUCTION}

Lake Rerewhakaaitu is a shallow lake in the Rotorua region and is unique amongst the 12 Rotorua Lakes in that its catchment is the only one dominated by dairy farming as the main type of land use. At present, Lake Rerewhakaaitu is an attractive and popular lake with fairly good water quality, although over recent years the lake has shown signs of declining, water quality and biodiversity. It is essential that water quality in the lake is maintained or improved in order to retain the intrinsic, cultural and economic benefits the lake provides to the region. Concern over water quality of Lake Rerewhakaaitu has primarily arisen from intensification of dairy farming in the lake catchment. Best management practices on farms are encouraged to protect lake water quality and catchment management plans are being prepared by local farmers. One tool available to lake managers is the use of computer models of lake ecosystems, which can be used to simulate current lake conditions and assess the potential impact of changes such as climate, land use, inflows, and farm management practices. This study aims to implement, calibrate and validate the coupled hydrodynamicecological model, DYRESM-CAEDYM, to Lake Rerewhakaaitu.

\section{LAKE REREWHAKAAITU STUDY SITE}

Lake Rerewhakaaitu is a mesotrophic, relatively small (740 ha) but shallow (average depth 7m, maximum depth $15 \mathrm{~m}$ ) lake located in the mid-west of the Rotorua Lakes region (Figure 1). The Mangakino stream feeds into Lake Rerewhakaaitu. Surface outflows occur only during high lake levels via drains to Mangaharakeke stream, a tributary of the Rangitaiki River. Additionally, overflows occur to the Mangaharakeke Stream and Rangitaiki River during high lake levels. Strong winds mix the water column causing the lake to be well mixed for the majority of the year. Two aquifers in the Lake Rerewhakaaitu catchment have the potential to discharge into the lake (White et al., 2003). These aquifers are Onuku Pyroclastic Aquifer $\left(8.48 \mathrm{~km}^{2}\right)$, and the Kaharoa/Waiohau Pyroclastic Aquifer $\left(10.32 \mathrm{~km}^{2}\right)$. All outflows are believed to be groundwater outflows.

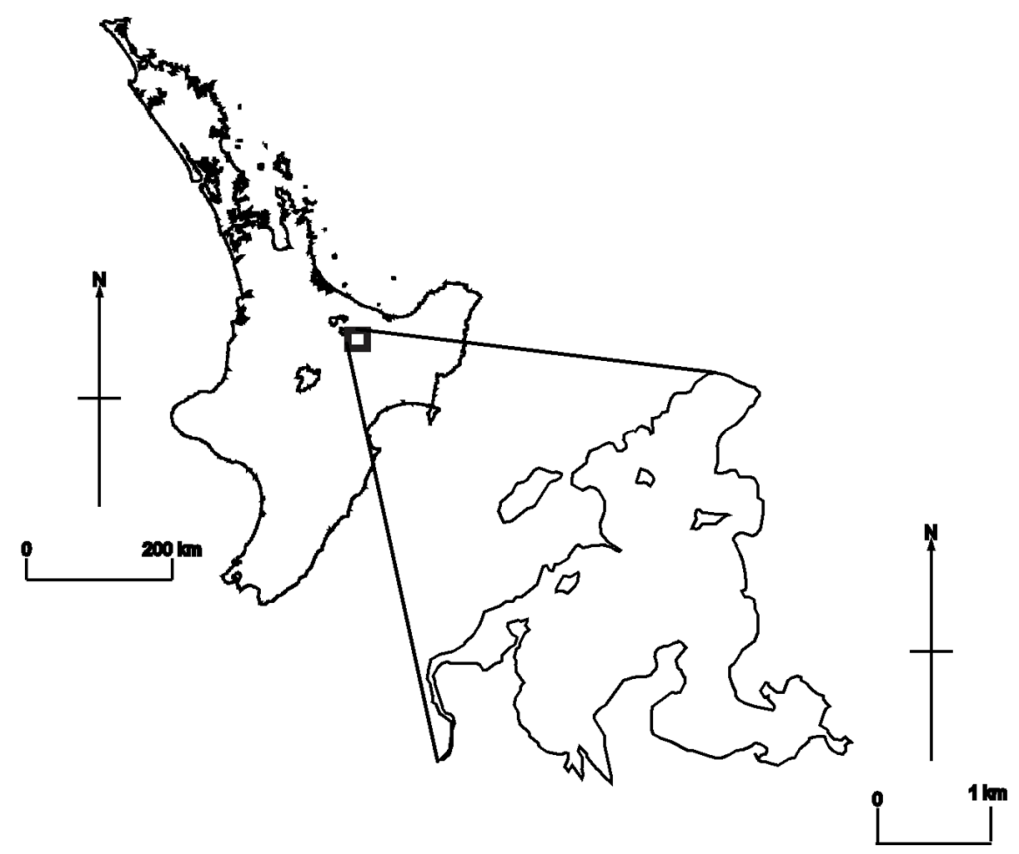

Figure 1. Location of Lake Rerewhakaaitu in the Rotorua Lakes District.

\section{HYDRODYNAMIC ECOLOGICAL MODEL}

The one-dimensional (1D) hydrodynamic model DYRESM (version 3.1.0-03) was coupled with the aquatic ecological model CAEDYM (version 3.1.0-06), to simulate water quality in Lake Rerewhakaaitu. Both models were developed at the Centre for Water Research (CWR), The University of Western Australia. DYRESM resolves the vertical distribution of temperature, salinity, and density in lakes and reservoirs, while CAEDYM simulates time varying fluxes of biogeochemical variables (e.g., nutrient species, phytoplankton biomass). The model includes comprehensive process representations for carbon (C), nitrogen (N), Phosphorus (P), and dissolved oxygen (DO) cycles, and several size classes of inorganic suspended solids. The variables in CAEDYM may be configured according to the objectives of the model application and availability of data. For example, it is possible to simulate up to seven different phytoplankton groups, five 
zooplankton groups, fish, and macrophytes. In this study, three groups of phytoplankton were included in CAEDYM, represented by cyanophytes, chlorophytes and a combined group termed diatoms. The interactions between phytoplankton growth and losses, sediment nutrient fluxes and the mineralisation and decomposition of particulate organic matter influence $\mathrm{N}$ and $\mathrm{P}$ cycling in the model. Fluxes of dissolved inorganic and organic nutrients from the bottom sediments are dependent on the temperature, $\mathrm{NO}_{3}-\mathrm{N}$ and $\mathrm{DO}$ concentrations of the water layer immediately above the sediment surface with the calibration of parameters specific to each application.

\subsection{DYRESM-CAEDYM Configuration}

Monitoring data from Lake Rerewhakaaitu (The University of Waikato, unpubl.) show strong dominance of chlorophytes in Lake Rerewhakaaitu, with occasional populations of diatoms, some very high (e.g. July 2010) and negligible presence of other taxa. Therefore, in this study only chlorophytes and diatoms were simulated in CAEDYM. Because silica concentrations in Lake Rerewhakaaitu are particularly low (Bay of Plenty Regional Council (BoPRC), unpubl.), $\mathrm{SiO}_{2}$ was also simulated, in order to account for silica limitation on diatom populations. No higher biology or macrophytes are included in the application of CAEDYM described here, rather, grazing effects are accounted for by slightly higher coefficients of phytoplankton respiration/mortality.

\subsection{Bathymetry}

Lake bathymetric data were obtained from the Bay of Plenty Regional council and taken on 13 April 2011. Lake volume and surface area were calculated excluding a small basin on the northwest of the lake. A depth vs area and depth vs volume graph was derived based on 37 data points.

\subsection{Meteorological Input}

Daily meteorological data from the Rotorua Airport climate station (Station 1770) c. 50m from Lake Rotorua and about $20 \mathrm{~km}$ from Lake Rerewhakaaitu were used in this study.

\subsection{Lake water balance}

The Lake Rerewhakaaitu water balance was calculated carried out using the following water balance equation:

$$
\frac{\Delta V}{\Delta t}=Q_{S I}+Q_{G I}-Q_{S O}-Q_{G O}+P A_{S}-E
$$

where $V$ is the lake volume at time $t$ (days), $Q_{S I}$ is the surface inflow $\left(\mathrm{m}^{3} /\right.$ day), $Q_{G I}$ is the groundwater inflow $\left(\mathrm{m}^{3} /\right.$ day), $), Q_{S O}$ is the surface outflow ( $\mathrm{m}^{3} /$ day), $Q_{G O}$ is the groundwater outflow $\left(\mathrm{m}^{3} /\right.$ day), $P$ is the precipitation on the lake (m//day), $A_{S}$ is the surface area of the lake $\left(\mathrm{m}^{2} /\right.$ day), and $E$ is the evaporation from the lake ( $\mathrm{m}^{3} /$ day). Two surface streams enter the lake: the Mangakino Stream and the Awaroa Stream. Two groundwater aquifers in the catchment have the potential to discharge water into Lake Rerewhakaaitu: the Onuku Pyroclastic Aquifer and the Kaharoa/Waiohau Pyroclastic Aquifer. However, these aquifers were not considered in this study nor were any groundwater outflows.

\subsection{Evaporation from the lake}

Evaporation from the lake was calculated as a function of wind speed and air vapour pressure from the daily average evaporative heat flux (Fischer et al., 1979; eqn 6.20) using meteorological input data and water temperature.

$$
Q_{l h}=\operatorname{minimum}\left(0 \geq \frac{0.622}{P_{\text {atm }}} C_{L} \rho_{A} C_{E} U_{A}\left(e_{A}-e_{A}\left(T_{S}\right)\right) \Delta t\right)
$$

where $Q_{l h}$ is the evaporative heat flux $\left(\mathrm{J} \mathrm{m}^{-2} \mathrm{~s}^{-1}\right), P_{a t m}$ is atmospheric pressure $(\mathrm{hPa}), C_{L}$ is he latent heat transfer coefficient for wind speed at a height of $10 \mathrm{~m}\left(1.3 \times 10^{-3}\right), \rho_{A}$ is the density of air $\left(\mathrm{kg} \mathrm{m}^{-3}\right), L_{E}$ is the latent heat evaporation of water $\left(2.453 \times 10^{6} \mathrm{~J} \mathrm{~kg}^{-1}\right), U_{a}$ is the wind speed in at $10 \mathrm{~m}$ height above ground level $\left.\mathrm{m} \mathrm{s}^{-1}\right), e_{s}\left(T_{s}\right)$ the saturation vapour pressure at the water surface temperature (hPa), and $e_{a}$ is the vapour pressure of the air $(\mathrm{hPa})$. The condition that $Q_{l h} \leq 0$ is so that no condensation effects are considered. For the purposes of determining daily water evaporated from the lake surface, daily surface lake water temperature was estimated from linear regression line of a 16-day average air temperature and measured monthly surface water temperatures between 1990 and 2015. The saturated vapour pressure $e_{s}\left(T_{s}\right)$ was calculated via the 
Magnus-Tetens formula (TVA 1972, eqn 4.1). The change in mass in the surface layer (layer N) due to latent heat flux is calculated as:

$$
\Delta M_{N}^{l h}=\frac{-Q_{l h} A_{S}}{L_{V}}
$$

where $\Delta M_{N}^{l h}$ is the change in mass in $\mathrm{m}^{3} \mathrm{~s}^{-1}$, and $L_{V}$ is the latent heat of vaporisation for water.

\subsection{Surface inflows and outflows}

Surface flow measurements for the Mangakino Stream were available from the BoPRC as part of a regular monitoring program. There were 101 measurements available for the period July 1995 - Jan 2015 of which 83 measurements fall within the simulation period (i.e. 2005-2015). To obtain daily flow for the Mangakino Stream, the total of 101 measurements were linearly correlated with rated flows in the permanently gauged Ngongotaha Stream (Lake Rotorua catchment). For the purpose of this study, it was assumed (through regression analysis) that the daily Awaroa Stream flows $=0.19 \times$ Mangakino Stream flows. It was assumed that $7 \%$ of the catchment area drained directly to the lake.

\subsection{Inflow parameterisation}

To estimate surface temperature of the Mangakino and Awaroa stream inflows, a cosine function was applied to describe variations within each year:

$$
T_{s}=a \cos (\omega t+\sigma)+T_{0}
$$

where $T_{s}$ is the derived water temperature $\left({ }^{\circ} \mathrm{C}\right), a$ is the amplitude $(\mathrm{m}), \omega$ is the angular frequency $(2 \pi / 365.25), \sigma$ is the phase angle, $T_{0}$ is the mean water temperature $\left({ }^{\circ} \mathrm{C}\right)$, and $t$ is time in days. The model parameters $a$ and $\sigma$ were estimated from data. For the Awaroa stream, most data were available only for 2010-mid 2012 and these data points were used to model stream temperature for the entire simulation period. Dissolved oxygen concentrations of both inflows were estimated as a function of water temperature (Bryers, NIWA, pers comm.).

\subsection{Nutrients and suspended sediments in stream flows}

Daily nutrient concentrations $\left(\mathrm{NO}_{3}-\mathrm{N}, \mathrm{NH}_{4}-\mathrm{N}, \mathrm{PO}_{4}-\mathrm{P}\right)$ for the Mangakino Stream were derived from interpolation between monthly samples from BoPRC stream monitoring data (monthly sampled between 2005-2015) to obtain daily values, as outlined for other model applications to Te Arawa lakes (Özkundakci et al., 2011). Labile organic nitrogen and phosphorus concentrations were calculated from monthly stream nutrient measurements and were evenly divided into dissolved and particulate fractions. Long-term measurements of nutrient concentrations for the Awaroa Stream were sparse and the dataset was considered not suitable for the interpolation method over the simulation period. Between 2006 and 2015, there were 14 measurements of nutrient and suspended solids concentrations available and from these, and limited data, an average concentration for all nutrient species and suspended sediments was assumed.

\subsection{Model initial conditions}

Water quality data collected by the BoPRC were used to initialise the lake model for all simulated variables. For this, data collected from the nearest date of the start of the simulation period was used and constant values assigned throughout the entire water column.

\subsection{Model calibration and validation}

DYRESM-CAEDYM was calibrated against field data for a five-year period between July 2005 and June 2010 and validated for a five-year period between July 2010 and June 2015 for variables of temperature, DO, $\mathrm{PO}_{4}-\mathrm{P}, \mathrm{TP}, \mathrm{NH}_{4}-\mathrm{N}, \mathrm{NO}_{3}-\mathrm{N}$ and $\mathrm{TN}$ in the surface mixed layer (averaged for $0-12 \mathrm{~m}$ ) in the lake, using monthly samples collected by BoPRC for the same integrated depth. The three simulated phytoplankton groups collectively contributed to a total simulated chlorophyll $a$ concentration, but with cyanophytes dominating during summer and chlorophytes during autumn and diatoms during winter and early spring, in a sequence similar to what have been observed previously in Lake Rerewhakaaitu (Scholes et al., 2011). Model parameters were adjusted manually using a trial and error approach with values set to within literature ranges (e.g., Schladow and Hamilton, 1997). The model error was represented by a series of model performance statistics, including the root-mean-square-error (RMSE), mean absolute error (MAE), mean signed difference (MSD) and comparison of the means of both the observations $\left(\mathrm{Mean}_{\mathrm{obs}}\right)$ and model ouput $\left(\mathrm{Mean}_{\mathrm{mod}}\right)$. We 
furthermore compared the coefficient of variation (CV) between model output and observations. The rootmean-square-error (RMSE) and Pearson correlation coefficient (R), was quantified for each output variable after each simulation for which model parameter values were adjusted. Calibration continued until there was negligible improvement in RMSE and R values with repeated model simulations. The final model parameters from the calibration were then fixed for model validation over the five-year period July 2010-June 2015.

\section{RESULTS AND DISCUSSION}

\subsection{Model calibration and validation}

Simulated time series of temperature and oxygen concentrations are given in Figure 2 for the top $1 \mathrm{~m}$ and bottom $12 \mathrm{~m}$. The model parameters adjusted during the calibration of DYRESM are presented in Table 2 . For a detailed description of the model calibration and validation, please refer to Parshotam et al. (2015).
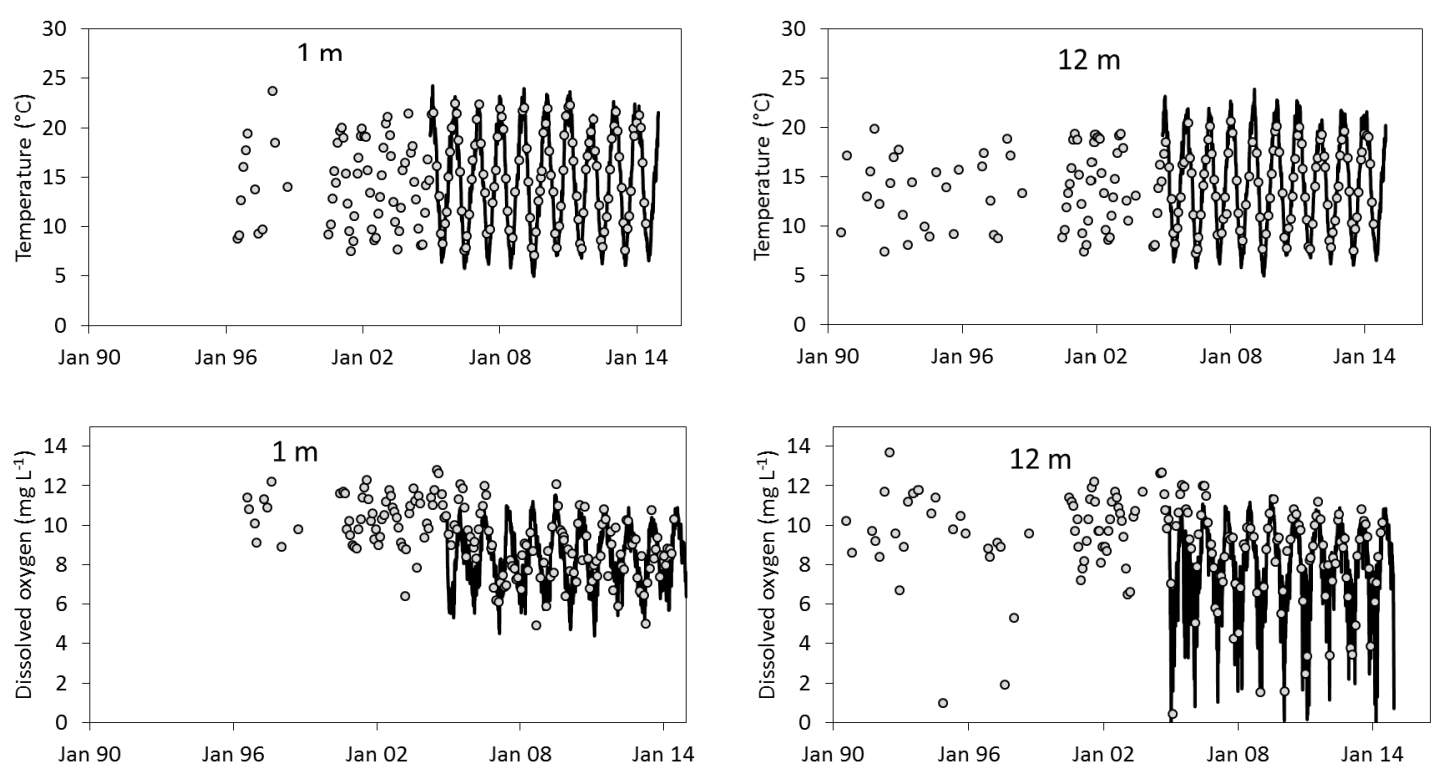

Figure 2. Predicted temperature and dissolved oxygen at $1 \mathrm{~m}$ and $12 \mathrm{~m}$. Dots represent observed data (where available) and solid lines represent simulated data during 2005-2015.

Table 2. Assigned values for parameters used in DYRESM for Lake Rerewhakaaitu.

\begin{tabular}{lll}
\hline Parameter & Unit & Value \\
\hline Critical wind speed & $\mathrm{m} \mathrm{s}^{-1}$ & 3.00 \\
Emissivity of water surface & - & 0.96 \\
Mean albedo of water & - & 0.1 \\
Potential energy mixing efficiency & - & 0.2 \\
Shear production efficiency & - & 0.21 \\
Wind stirring efficiency & - & 0.2 \\
Vertical mixing coefficient & - & 600 \\
Effective surface area coefficient & $\mathrm{m}^{-2}$ & $1.45 \times 10^{6}$ \\
\hline
\end{tabular}

Sediment parameters, nutrient cycling and phytoplankton parameters, used during the calibration of CAEDYM were assigned mostly within the range found in the literature (e.g., Schladow and Hamilton 1997). Visual comparisons of nitrate, $\mathrm{PO}_{4}-\mathrm{P}, \mathrm{TP}, \mathrm{NH}_{4}-\mathrm{N}$, and $\mathrm{TN}$ concentrations with field measurements are shown in Figure 3 for the lake surface $(0 \mathrm{~m})$ and bottom $12 \mathrm{~m}$. $\mathrm{NO}_{3}-\mathrm{N}$ concentrations are not shown here.

For a detailed description of the model calibration and validation, including statistics (summarised in Table 3), please refer to Parshotam et al. (2015). 

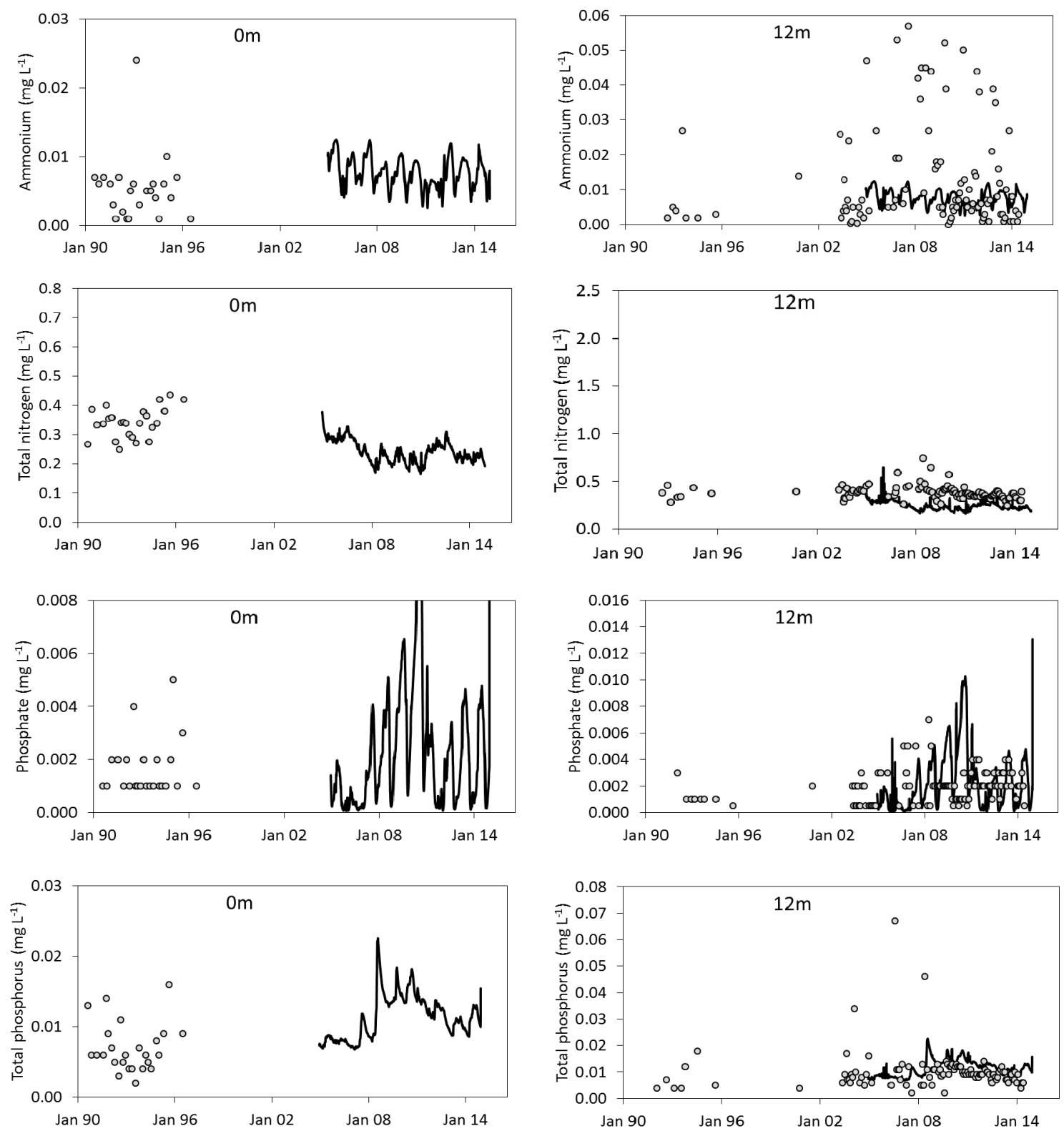

Figure 3. Comparison of model simulations (continuous grey line) against field observations (circles) at the surface $(0 \mathrm{~m})$ and near-bottom $(12 \mathrm{~m})$ of Lake Rerewhakaaitu from 1990 when data was available, and during the calibration (2005-2010) and validation (2010-2015) periods for ammonium, total nitrogen, phosphate and total phosphorus. The high NH4 values at $12 \mathrm{~m}$ are not well represented by the model but is well represented at depths $0 \mathrm{~m}, 0 \mathrm{~m}, 6 \mathrm{~m}, 10 \mathrm{~m}$ (Figures not shown). Visual comparisons of chlorophyll $a$ with field measurements are shown in Figure 4 for the whole lake column (0-12).

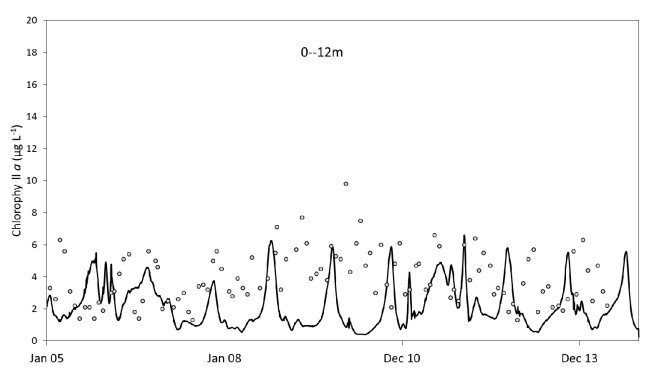

Figure 4. Comparison of model simulations (continuous grey line) against field observations (circles) of chlorophyll $a$ throughout the whole column during the model calibration and validation period. 
Parshotam et al., A hydrodynamic-ecological model for Lake Rerewhakaaitu

Table 3. Model error statistics for the calibration (2005-2010) and validation (2010-2015) periods.

\begin{tabular}{llrrrrrr}
\hline \multirow{4}{*}{ Validation } & TP & TN & NNN & NH4 & \multicolumn{1}{c}{ DRP } & Chla \\
& Model Mean & 0.010 & 0.264 & 0.033 & 0.008 & 0.0019 & 2.451 \\
& Obs Mean & 0.009 & 0.381 & 0.012 & 0.019 & 0.0037 & 3.640 \\
& Pearson & 0.219 & -0.384 & 0.156 & -0.226 & -0.0026 & -0.096 \\
RMSE & 0.005 & 0.250 & 0.037 & 0.024 & 0.0060 & 2.453 \\
MAE & 0.004 & 0.220 & 0.025 & 0.015 & 0.0030 & 2.013 \\
& MSD & 0.001 & -0.150 & 0.020 & -0.012 & -0.0018 & -1.1203 \\
& N & 51 & 41 & 51 & 55 & 53 & 53 \\
Model Mean & 0.012 & 0.233 & 0.029 & 0.007 & 0.0027 & 2.514 \\
& Obs Mean & 0.010 & 0.365 & 0.006 & 0.010 & 0.003 & 4.061 \\
& Pearson & 0.395 & -0.213 & 0.066 & -0.307 & -0.111 & -0.198 \\
RMSE & 0.003 & 0.136 & 0.046 & 0.028 & 0.011 & 3.133 \\
MAE & 0.003 & 0.126 & 0.024 & 0.008 & 0.002 & 2.533 \\
MSD & 0.002 & -0.126 & 0.023 & -0.004 & 0.000 & -1.472 \\
& N & 49 & 49 & 51 & 53 & 49 & 54 \\
\hline
\end{tabular}

\section{CONCLUSIONS AND RECOMMENDATIONS}

A functional DYRESM-CAEDYM model of Lake Rerewhakaaitu has been established, with reasonable representation of water and nutrient sources to and from the lake, and acceptable performance as indicated by model error statistics. Opportunities exist for improving the accuracy and usefulness of the current model, including refinement of input data and extension of the date range covered by the model, and further calibration. Further development of the model should address groundwater inflows and outflows. The model may be used as a decision support tool for testing various scenarios of lake and land management actions.

\section{ACKNOWLEDGMENTS}

The authors would like to thank the Bay of Plenty Regional Council for supporting the project.

\section{REFERENCES}

Fischer, H.B., List, E.J., Koh, R.C.Y., Imberger, J. and N.H. Brooks (1979). Mixing in Inland and Coastal Waters. Academic Press, New York, 483 pp.

Özkundakci, D., Hamilton, D. P. and D. Trolle (2011). Modelling the response of a highly eutrophic lake to reductions in external and internal nutrient loading. NZ J. Mar. Freshwater. Res. 45: 165-185.

Parshotam, A., Özkundakci, D., McBride, C. and D. Hamilton (2015). A water quality model for Lake Rerewhakaaitu. Report prepared for Bay of Plenty Regional Council. Environmental Research Institute.

Schladow S.G. and D.P. Hamilton (1997). Prediction of water quality in lakes and reservoirs: Part II-Model calibration, sensitivity analysis and application. Ecological Modelling 96, 111-123.

Scholes P. (2011). 20010/2011 Rotorua Lakes TLI update. Bay of Plenty Regional Council Environmental Publication 2011/17.

Tennessee Valley Authority (1972). Heat and mass transfer between a water surface and the atmosphere. Tennessee Valley Authority (TVA) Report 0-6803, Norris, TN.

White, P.A., Tait, T., and R.R. Reeves (2003). Identifying leakage to groundwater in the lake Rerewhakaaitu catchment. Report prepared for Environment Bay of Plenty, August, 2003. Client report: 2003/62. 